\title{
The Conservative Party, the role of the state and the politics of protection, c.1918-1932
}

\begin{abstract}
The Conservative Party was in government for almost all of the decade after the First World War, during which it faced not only economic problems but also the political threat of the advance of the Labour Party. Socialism raised the challenge of a greatly-extended role for the state, and in response to this and to tackle the difficulties of industry and the high level of unemployment, which Conservatives attributed to the free trade economy, the party returned in 1923 and 1930-32 to its pre-war advocacy of a system of tariff protection linked to imperial preference. These factors have previously been viewed from separate perspectives, and accounts of the development of the British state have treated Conservative attitudes as simply negative. This article explores the more varied strands of Conservative opinion about the role of the state in the inter-war period, and links these to the party's governing practice in key aspects of economic policy in the decade after 1918, and its attempts to introduce protective tariffs in 1923 and 1930-32. It is based upon contemporary discussions of Conservative principles and policies by active politicians and propagandists, and upon the private correspondence of the party's parliamentary leadership.
\end{abstract}

In the years immediately following the end of the First World War, British governments struggled to cope with economic stagnation and persistent high unemployment. The necessities of the war had demonstrated the potential for an expanded role for the state, both as the regulator of economic activity and as the provider of relief and assistance to those in difficulty. However, both of the prewar governing parties, Liberals and Conservatives, were distrustful of this power and regarded the wartime measures as expedients only, to be dismantled as part of the return to former normality. In this they were also motivated by the advance of the Labour Party, which professed an ultimate aim of expanding the role of the state to every aspect of economic activity - and perhaps, its opponents feared, to all spheres of personal life as well. For nearly all of the period between the Armistice and the onset of the depression in 1930, the Conservative Party were either the main or the sole party of government. However, the links between their ideas and attitudes about the role of the 
state and their approach to the problems of the economy and unemployment in government have been under-explored.

This period has been examined, usually briefly, in the surveys of the development of the modern British state, a narrative in which the two World Wars naturally take the most prominent part. ${ }^{1}$ Such accounts focus mainly upon government as legislator and administrator, being a history of measures and sometimes of men, but rarely of political ideas or tactics. A few specific themes have been discussed, but again the focus has been upon a particular policy or field of activity, in its individual context. ${ }^{2}$ The gap is all the greater because the few studies which directly consider the Conservative Party have been concerned with the intricate manoeuvres of 'high politics', and thus also have a limited perspective - if of a contrary, microcosmic, scale. ${ }^{3}$ This is in marked contrast to the considerable attention which has been devoted the ideas and policies of the Labour Party in this area, even though its two short spells of minority administration meant that it made little attempt to implement its programme. ${ }^{4}$ This was not the case for the main governing party of the era, and the following discussion explores Conservative opinion about the role of the state in the inter-war period generally, the Conservative Party's governing practice in key aspects of economic policy in the decade after 1918, and its attempts to introduce its favoured remedy of protective tariffs in 1923 and, finally and successfully, in 1930-32.

For British Conservatives in the inter-war era, the most important functions of the state were to restrain conflict within society and to marshal its strength so that it was defended from assault by other societies around it. ${ }^{5}$ The first of these required maintaining order, administering the statutes and acting as arbiter between competing groups and claims. The government alone was able to survey the whole scene, and was required by its duty to act as 'trustee of the interests of the whole community'. ${ }^{6}$ For that reason, 'economic forces which would have an anti-social effect must be checked by the authority of the state'. ${ }^{7}$ As the expression of a collective will and wisdom, the state had some rights of precedence over individual objections and conscience, and so prevented anarchy. ${ }^{8}$ However, the state was just a mechanism, and as such it did not have 'any exceptional or 
accumulated morality beyond that of the men who compose it' ${ }^{9}$ The proper purpose of the state was 'to permit the individual to expand his personality, develop his potentialities and thus contribute to the advancement of the community'. ${ }^{10}$

The Conservative ideal was a limited state whose role was focused upon protecting the liberty of the individual from abuse by others, rather than eroding it itself. Conservatives understood that liberties were not derived from the state, but on the contrary had to be upheld against it. An overmighty state posed grave dangers to the individualism and enterprise upon which a healthy society depended, for 'the state is a hard master'. ${ }^{11}$ This was particularly the case with a Socialist state that would be based on regulation, intervention and perhaps outright confiscation, but it was also the case in the existing system at the point where the state most regularly impacted upon the owners of property: the levels and forms of taxation. Cecil argued that 'it is impossible for the State equitably to distinguish between one kind of property and another', and that it was wrong to place heavier burdens on a particular group or trade: 'to tax a class specially is to punish them; to punish except for crime is unjust'. In that respect, 'taxation is distinguished from confiscation only in degree'. ${ }^{12}$

Conservative views about the proper role of the state were the product of two strands of thought, which have been described as 'paternalist' and 'libertarian'. ${ }^{13}$ However, individual Conservatives cannot be neatly pigeonholed into one or other of these categories, as their views on different issues often varied between them. These positions were neither absolute nor mutually exclusive, for state action 'should be freely used to defend individual liberty and dignity'. ${ }^{14}$ Conservative responses were issue-related rather than the product of an overarching theory; the determining factor was not the abstract concept of the state in itself, but immediate perceptions of the working of 'the agencies of civil society'. ${ }^{15}$ No state intervention was desirable where these voluntary and independent economic and social organisations were effective, but where they were not working properly then action by the state had become necessary - although time should be allowed before it was certain that steps should be taken, and these should be the minimum to render them effective again. The variation as to which agencies were seen at any time to be functioning 
inadequately explains the differing judgements as to where and how the state should act. Conservatives started from 'a healthy prejudice' in favour of private enterprise, but 'when something different is needed they are prepared to accept whatever method is preferable'. ${ }^{16}$ On the surface, this could seem inconsistent or to be no more than a form of 'patch the leaks' pragmatism. However, it was founded upon the view that society had to be regulated and supported in certain ways, and that it was the duty of government to see this carried out by means which were consistent, economical and balanced the need for efficiency and cohesion with the liberties of the individual. Informing this was the sceptical current which was one of the fundamental components of the Conservative outlook, producing a predisposition against state action and the feeling that it should be employed only where clearly necessary - of which wartime was the best example. Conservatives were always reluctant to enlarge the economic role of goverment in peacetime, and their underlying view was 'that government intervention should be invited by industry, not forced upon it. ${ }^{, 17}$

Two other considerations held back the Conservatives from enlarging the scope of government: first, that they had no desire to establish precedents which their opponents could exploit and might dangerously extend; second, that the effects of intervention were difficult to predict and control, for 'the State is a clumsy, rigid instrument difficult to handle and operating heavily and unexpectedly'. ${ }^{18}$ Conservatives were thus doubtful of the wisdom or practicality of intervention by the state in customary relationships, as this was likely to take the form of crude and simplistic regulation of what had evolved in complex and subtle ways. However, this did not entail an absolute proscription against state intervention, and there was regular emphasis that any such rigid view was descended from 'Cobdenite' Liberalism and the claim that state action was contrary to Conservative principles 'has no foundation'. ${ }^{19}$ Instead, Conservative attitudes were governed by the understanding that 'the State is not simple but complex, not uniform but a harmony of opposites'. ${ }^{20}$

The widespread over-simplification that Conservatism was opposed in principle to action by the 
state was largely a by-product of the defence of the existing economic system against Socialism. This became a central political issue in the inter-war period due to the rise of the Labour Party and its specific attacks on the deficiencies of capitalism. Conservatives defended capitalism as a system which had proven itself through the rise in living standards from which all classes had benefitted since the Industrial Revolution, which was responsive to public demands, and which required much less in the way of regulation and bureaucracy than any alternative. ${ }^{21}$ It had the advantages of enterprise, invention, openness and efficiency, and its benefits came with comparatively little financial cost in terms of the burden of taxation. Conservatives were rather more uneasy about some of the social costs which might be involved, and for that reason they never favoured the unrestrained operation of market forces or what they regarded as the Liberal policy of pure laissez-faire. ${ }^{22}$ This would have a dissolving effect upon the social bonds to which they attached greater importance, and this explains the hostile reaction of many Conservatives to the endorsement of competition and ambition in the Earl of Birkenhead's famous Rectoral Address of 1924; this was seen as 'the gospel of sordid, self-assertive greed (and contempt for the under$\operatorname{dog}),{ }^{23}$ which was 'the very point of view which the war has rendered definitely hateful. ${ }^{24}$ Instead, 'it must be the duty of anything calling itself a society to keep the balance between its members', ${ }^{25}$ and the role of government was to protect those unable to look after themselves.

Whilst the Conservatives had absorbed much of the laissez-faire outlook of the Victorian era, they were always more authoritarian and more pragmatic in their attitudes to the role of the state than the Liberals. ${ }^{26}$ The test was one of necessity, and it was where this produced unclear results that there was hesitancy or disagreement. When faced with the demands of the world wars, the Conservatives were willing to suspend the normal rules in an overriding drive to prosecute the war with the fullest commitment. Powers were taken to provide manpower through conscription and to control industrial production, transport, the rationing of food and other goods, the movement of citizens, the internment of aliens and the censorship of the press. Conservatives were willing to adopt compulsion, but at the same time were careful to ensure compensation for infringements of 
property rights. Where government assumed the direction of private industry, a 'fair' rate of return for owners and shareholders had to be furnished, but anything in the nature of wartime profiteering offended against patriotism and aroused Conservative hostility. There was an assumption that such expedients were temporary, and there was a strong desire to return to 'normality' after the war and dismantle the innovations which had been made. However, there were always areas where this proved to be impossible or undesirable, and the sphere of state responsibility was permanently enlarged by each World War. Even so, this was always on an empirical basis, with each instance justified by its particular circumstance and not by any general theory. ${ }^{27}$

In time of peace, the Conservative Party was more reluctant to enlarge the role of the state, not least because - whatever the original intention - such extensions would become normal and permanent. This was shown in the party's reaction on various occasions, such as the coal subsidy of 1925, the slum clearance provisions of the mid-1930s, and Neville Chamberlain's proposed National Defence Contribution of $1937 .{ }^{28}$ However, the experience of the First World War made it more likely that governments would consider a greater element of state intervention in important areas that proved intractable to a more conventional approach. These were particularly industrial unemployment and agricultural depression, and between the wars Conservative ministers employed a variety of measures to tackle these including import quotas, subsidies, marketing boards, rationalisation schemes and regional aid. There was little criticism in the mid-1920s of the construction of a national electricity grid, as this was a task of investment and organisation which only government could undertake. The Factory Acts were a form of intervention in the market place and proposals to extend them in the late 1920 s caused some unease, but this was muted as regulation in this area was legitimised by the much-trumpeted Tory tradition of such measures dating back to Lord Shaftesbury in the early nineteenth century.

In the inter-war period, there was no doubt that the core heavy industries of the industrial revolution - coal, iron and steel, engineering and textiles - were suffering from sustained depression. Conservatives attributed this partly to 'unfair' foreign competition which was 
'dumping' subsidised imports into the domestic and colonial markets (and to which tariffs were the answer), but they were also aware of the problems of under-investment, over-capacity, inefficiency and complacent management. The problems were complex and interwoven; in 1923 the cabinet minister Leo Amery pointed out "the "tax nexus" which links all our industries together and makes each dependent for its success on the prosperity and maintainence of the rest'. ${ }^{29}$ Simple and drastic remedies - in particular, the nationalisation advocated by the Socialists - seemed unlikely to work, and Conservatives were reluctant to impose solutions from above. The role of the state was not to direct industry, but to hold the ring in order to enable rationalisation and modernisation to be implemented from within. The crucial distinction was between the state acting as the defender and helper of industry, and as its owner and controller; the two latter were Socialism, whilst the two former were not. However, there was almost no acknowledgement of the fact that the introduction of protectionism would inevitably extend the economic role and power of the state, even if this was for the beneficial purpose of sheltering industries that were in difficulty and maintaining their workers' standard of living.

The younger and more left-wing of the inter-war Conservative MPs tended to regard the role of the state more positively, or - as their critics from the centre and right would argue - to see its benefits in more naïve and simplistic terms. Other sections of Conservative opinion were more cautious, but the one area where all were agreed and unhesitating in affirming the role of the state was public order. This included the maintenance of essential services during the General Strike, the restraints placed on extremist political groups in the Public Order Act of 1937, and the retention by the state of ultimate control over radio broadcasting: 'the Government must retain its monopoly', in order to have 'control over an agency which in time of trouble might spell positive disaster if controlled by the wrong people'. ${ }^{30}$

However, all shades of Conservative opinion considered that an undesirable consequence of the extension of state activity was the growth of bureaucracy. This was a greater potential threat to liberty than any absolute monarch, for the scale and scope of a modern bureaucracy meant that 'its 
hand is in all pockets and its rod on all backs,. ${ }^{31}$ It had the tendency to become self-perpetuating: 'it is the work which the bureaucracy has to create to justify its own existence which mulcts the taxpayer'. ${ }^{32}$ The party was particularly suspicious of measures which extended the disrectionary powers of ministers or officials, such as clause four of the Ministry of Ways Bill in March 1919, only a few weeks after the end of the war. This clause 'gives the Minister power to take over almost anything by Order in Council'; it provoked a unanimous hostile resolution from the backbench Unionist War Committee and a deputation to the party leader, and the bill was only passed when the offending clause was dropped. ${ }^{33}$ The dislike of interventionism and regulation on grounds of principle was reinforced by the view that civil servants lacked the frame of mind, skills and practical experience necessary to conduct a business: 'all the available evidence indicates that State enterprise is inherently unenterprising, ${ }^{34}$ It was considered self-evident that the intrusion of the state and its servants into such matters was bound to be inefficient, and that the free market, with its 'manifold and varied channels of trade', was more natural and effective than any 'rigid, inelastic' state organisation. ${ }^{35}$

The long-established and fundamental activity of the state was the raising of the funds necessary for government. This became a significant issue after the First World War due to the combination of the much greater incidence of taxation and the depressed state of the economy. The huge cost of the war had resulted in a massive increase in the National Debt (the interest on which was a major burden on post-war budgets) and a steep rise in direct taxation. From the standard rate set in the 1909 'People's Budget' of 1s. 2d. (6\%) in the pound, income tax mounted to 5s. (25\%) during the war and in the 1919 budget was raised to 6s. (30\%). The effect of inflation, with the cost of living peaking at 269 in November 1920 compared to the baseline of 100 at the outbreak of war, and the consequent rise in incomes was that more people found themselves coming into the unchanged tax band: in 1914 only 6\% of earners paid any direct tax, but by 1920 this had risen to $38 \%$. To these burdens were added the continuing impact of the death duties introduced in the 1890s, the higher level of local rates (especially on shops and businesses) which resulted from the 
expanded duties placed on local government, and the increase in the Excess Profits Duty in the 1919 budget - aimed at unpopular wartime profiteering, but like so many fiscal nets catching a good many others as well. All of this particularly hit the agricultural sector, which had suffered long depression before 1914, and it contributed to the large extent of land sales in 1919-21 and its consequent impact on traditional relationships in rural society.

As it was led at every level by those who paid taxes and received comparatively little visible benefit from the expansion of state activity, it was hardly surprising that in times of economic depression the Conservative Party called for the reduction of expenditure and thereby also of taxation more stridently than anything else. The demand for 'economy' became a constant refrain, as it was never more than marginally satisfied. Even the 'Geddes axe' slashing of expenditure in 1921 made comparatively little difference to the level of taxation, especially as it coincided with a recession. The most serious attempts after this were Churchill's pursuit of a traditional style of Treasury budget restriction as Chancellor from 1924 to 1929, and the savings agreed in the emergency of the August 1931 crisis by the newly-formed National Government. The desirability of reducing expenditure was never disputed by Conservative leaders, but they feared the effect on a mass electorate of the scale of retrenchment that would be needed to make an appreciable impact, and so constantly disappointed their supporters' unrealistic expectations. The problem was that 'unless you scrap things that really matter', it was impossible to make more than marginal savings. ${ }^{36}$ However, the advocates of 'really sweeping economies' believed that 'while they may make the Government unpopular for the moment, [they] will bring their own reward by an improvement in trade and more employment for the people'. ${ }^{37}$ The pressure for economy in the 1920s was given added impetus by the campaigns of Lord Rothermere in the Daily Mail, most famously and effectively in the creation of the Anti-Waste League in 1920, and also during the 1924-29 government and as part of the platform of the United Empire Party in 1930-31. The most that it led to was some reduction in the number of civil servants in the early 1920s and the proposal inserted at the last minute in the 1927 budget to abolish some minor departments and posts, such as 
the Minister of Mines, some of which was fairly soon afterwards found to be counter-productive. ${ }^{38}$ A taste of how far the rank and file might have gone can be seen in the proposals drawn up by the 1922 Committee's economy enquiry of 1932 - and these were swiftly repudiated when most MPs found them far too strong a medicine to swallow. ${ }^{39}$ However, this was not the end of the story, and calls for 'economy' were heard during the slump years of the early 1930s and recurred at the end of the decade under the pressure of paying for the rearmament programmes - although here, as Conservatives generally approved the nature of the expenditure if not its causes, it was more ambivalent, and focused either on the need to cut back on social programmes to ease the strain on national resources or returned to the old chestnut of eliminating waste.

During the 1920s the problems of the coal industry were at the forefront, with strikes and threatened strikes in 1920-21, the subsidy of 1925, the General Strike in 1926 and lock-out of 192627, and repeated demands for the nationalisation of the industry. The latter the Conservatives would not consider, although they despaired of the negative attitude of the coal-owners. These were an unpopular group capable of the most inept tactics, and were seen to be as much of a problem as the equally inflexible miners' union, but the legal rights of the owners could not be ignored. $^{40}$ During the problem period of $1925-7$, the Baldwin cabinet sought as far as possible to maintain a position of neutrality, and ministers were careful not to take a line that was too close to that of the employers. ${ }^{41}$ The government's solution, once peace in the industry could be obtained, was to promote rationalisation and the closing or merger of uneconomic pits, and in 1921 it had been contemplated to use the new safeguarding legislation to provide the umbrella beneath which such restructuring could occur.

The Conservative approach to the problems of industry concentrated upon encouraging rationalisation and greater efficiency. It was concern about the impact on costs and so of competitiveness which caused the 1924-29 government's reluctance to adhere to the Washington Eight Hours Convention and led to doubts about Neville Chamberlain's Factory Acts, with Churchill arguing that the existing laws were already 'the most advanced' and 'most strictly 
enforced in Europe. $^{42}$ If the government carried neither a big enough stick nor carrot to bring about rationalisation and modernisation in industry, then its only remaining option (as state direction was ruled out) was to act as umpire and encourage conciliation and good relations between employers and workers - and so this was one of Baldwin most constant and eloquent themes. ${ }^{43}$ Another proposal on similar lines was 'co-partnership', which Robert Cecil (although already in the leftwards trajectory that led to his resignation from the cabinet in 1927) endorsed as 'right and conformable with every Conservative principle'. ${ }^{44}$ This was also advocated, under the term 'industrial co-partnery, or its halfway house, profit-sharing', by Skelton in 1924 and the 'YMCA' group of MPs in 1927. Such ideas were based on a recognition of the contribution of both capital and labour to 'the work of the production of wealth', and had the aim that 'the workers become capitalists' and thus have 'a new incentive and a new kind of interest in [their] work' ${ }^{45}$ The economic crisis of 1931 was met initially and almost instinctively by traditional deflationary methods, but the continuation of depression in the following years led to consideration of other possible stimulants to recovery. Conservatives generally ruled out programmes of public works, partly as too costly and partly because - if the projects were worthwhile - it was simply the state competing with private industry on unfairly subsidised terms. Some on the left of the party, particularly Macmillan, became interested in the ideas of planning, but for most Conservatives these were tainted by their Socialist origins. ${ }^{46}$ Instead, pragmatic measures were prefered, especially when the start of recovery left identifiable unemployment 'black spots' which could be targeted through regional policies such as the Special Areas Act of 1934.

Unemployment was the central economic and political concern of the interwar period. ${ }^{47}$ It was seen by Conservatives as the prime cause of working-class poverty and alienation, the problem ultimately most likely to lead to social breakdown and revolution, and in the short-term the main cause of the rapid advance of the Labour Party from 1920 to 1924. The fear of entering another winter of rising unemployment without a remedy was a key factor in Baldwin's decision to turn to protectionism in $1923 .^{48}$ The Prime Minister's address to his cabinet before the Plymouth speech 
was clear that 'there is only one way, not to cure, but to fight unemployment, and that is to protect the home market against foreign manufactures. ${ }^{49}$ The failure of this initiative led to the promotion of other remedies, though none received the same drive and impetus from the government. These included the promotion of rationalisation and modernisation in industry, and the emigration of surplus labour to the empire; shortly before the 1923 election Baldwin spoke to the Canadian Prime Minister of a concern that the population was too large and the solution was to move some of it overseas. $^{50}$ However, schemes of imperial emigration were left to private philanthropy to promote, if only becauses of their cost.

The other measures dealing with unemployment were palliative rather than preventative, and lead into the area of social policy. The most important of these was the existence of a statefinanced welfare safety-net, by means first of the National Insurance scheme and then, when the worker had exhausted the entitlement of his contributions, of transitional benefit - the 'dole'. This was accepted as essential in the industrial situation, although its effects were 'demoralising' and it encouraged an unhealthy dependency on the state. ${ }^{51}$ The main area of debate about unemployment relief was the appropriate level of the benefits, which involved several tangled issues. One of these was the simple burden on the Exchequer (particularly as the insurance fund needed subventions from tax revenue) and another the rise in the real value of benefits due to the deflation of the 1920s; both of these were central in the decision in the August 1931 crisis to reduce payments by ten per cent. There was also the point that benefits should not be more attractive than working for wages, and must be set below the lowest paid jobs; it was a fine line between deterring the work-shy and imposing grinding poverty on those genuinely seeking work, and after 1940 the public view that the system had been too harsh damaged the reputation of the National Government. The other aspects related to the role in the 1920 s of the Poor Law system in providing the basic level of support through 'outdoor relief'; i.e., payments to persons living in their own homes rather than compelled to enter the workhouse. The problem with this was that it was locally financed through the rates, and the areas with the heaviest unemployment were also the poorest in terms of businesses and 
ratepayers, who were thus hit particularly hard. A further political dimension was added to this in the early 1920s by 'Poplarism', named after the East End borough whose Labour councillors raised benefit levels deliberately in excess of their budget. This led to Neville Chamberlain's plans to reform the Poor Law and abolish the Boards of Guardians. Some of the cabinet were reluctant to tackle such a minefield and it was unpopular in some Conservative areas, where this quasicharitable role was attractive to those desiring some parochial status; the Chief Whip and Party Chairman agreed apprehensively that 'the political effect of the Poor Law bill would be disastrous'. 52

After this reform, benefits were still administered by local authorities and there were considerable variations, and so in the early 1930s this was rationalised into a single national scheme administered by a new body, the Unemployment Assistance Board. The problem was that when this came into effect in early 1935, the levels were generally set at the lowest used anywhere and thus a great many recipients experienced a sharp fall in income and a political crisis resulted. It was compounded by other difficulties which the government was simultaneously facing, and by the panic of the Minister of Labour, Oliver Stanley, who blamed his officials; a complete debacle was avoided only by the swift abandonment of the new rates and a restoration of the old. The anger which this had brought to the surface was also connected with the other highly unpopular feature of unemployment relief: the means test, which was both inquisitorially intrusive and had the effect of rewarding the indigent at the expense of the thrifty, which to Conservative eyes was indeed the worls turned upside down.

After the immediate post-war boom of 1919-20, in which inflationary pressures led to trade union militancy and threatened the fixed incomes and savings of the middle class, the governments of the inter-war period followed a deflationary policy. This began with the raising of the bank rate by Austen Chamberlain in April 1920, and was confirmed by Churchill's decision in 1925 to return to the gold standard at the pre-war parity with the US dollar. Aspects of this policy were criticised at some points and from some quarters, but never in any substantial or effective way. Whilst 
stability in the international exchanges was an advantage generally, the high parity made British exports uncompetitive and continued the loss of export markets. These policies prioritised finance and the international position of the City of London over the needs of manufacturing industry and agriculture. $^{53}$ They defended the social groups most likely to suffer from inflation: the middle class, and in particular savers, holders of national debt stock, pensioners and those on fixed incomes. The economy remained in a consistent state of stagnation and mild deflation during the decade from 1920 to 1930 , before the onset of severe recession in the wake of the stock market crash in the United States. The result was that in the 1920s the most visible trade and industrial problems were the difficulties of the old-established industries of coal, steel, engineering, shipbuilding and textiles to fill their order books from either the export or the home market. This problem, and the persistent level of unemployment of around one million which resulted, returned the prewar controversy of free trade versus protection to the centre of the political stage.

The proposal for tariff reform was the defining issue in Conservative politics in the first third of the twentieth century, from the opening of Joseph Chamberlain's campaign in 1903 to the introduction of protectionist duties by his younger son, Neville, as Chancellor of the Exchequer in 1932. Support for tariffs played the main part in four election defeats (1906, January and December 1910, and 1923), whilst disavowal of a fundamental element in the policy - duties on imports of food - was equally significant in the election victories of 1918, 1922 and 1924 . The paradox of tariff reform was that it aroused fervent support within the Conservative ranks despite its electoral disadvantages and the disunity which it created. The reason for this was that protectionism appealed to both idealism and self-interest - to the heart and the pocket. Chamberlain's foremost aim had been to make the empire more inter-dependent and united in order to maintain Britain's world position, and it was this patriotic and imperial agenda that captured the imagination of many Conservatives in the Edwardian era and explains the continuing support for tariffs amongst the rank and file despite the electoral setbacks.

The domestic economic and political benefits of tariff reform were of secondary importance to 
its most committed enthusiasts, but they offered an attractive solution to the concerns of many Conservative supporters. The protectionist aspect of tariff reform was seen as the remedy for unemployment, and would give the Conservatives a positive appeal to the working-class instead of reliance upon negative anti-Socialism. Henry Page Croft, the most constant backbench campaigner for tariffs, believed 'that real Protection will so alter our conditions that it will put us in power for many years. ${ }^{54}$ Tariff duties would protect industries from overseas competitors and raise new revenue in the process, and the appealing prospect that 'the foreigner will pay' would enable a reduction in income tax without the unpopularity of cutting social expenditure. However, some Conservatives remained doubtful about abandoning the economic system upon which Britain's prosperity as an industrial nation had been founded, and were instinctively reluctant to embrace such a radical measure; in its origins in Joseph Chamberlain's Liberal Unionism and the fervour and doctrinaire style of its most committed advocates, it was in spirit 'anything but a Conservative measure'. 55 Even so, and although it would involve the state in a new regulatory role, it was strongly supported by many who were otherwise firm opponents of state intervention in industry.

The tariff issue faded into the background between 1913 and 1922 due to the primacy first of Irish Home Rule and then of the war, and setting it aside had been an essential requirement for the continuation of the coalition in 1918. The economic problems of the early 1920s, when the gross domestic product fell by over 30\% from 1920 to 1924, highlighted concerns over imports of subidised or 'dumped' foreign goods and led to straightforward protectionism becoming increasingly attractive to many sectors of industry. ${ }^{56}$ The strength of support varied according to the circumstances of each sector, and some had a greater residual commitment to free trade or were more dependent upon importing cheap raw materials: banking, insurance and shipping were generally ambivalent or unconvinced, whilst the cotton textile industry of Lancashire was vigorously hostile. However, elsewhere there was widespread support for protectionism amongst landowners, businessmen and managers. ${ }^{57}$ Protective duties to defend industry were justified by the cry of 'unfair' (often a synonym for successful) foreign competition, and the claim that granting 
tariffs would give industries the shelter which they needed to embark on rationalisation and modernisation. Industrial protectionism required a significant change from Britain's customary approach of free trade, but it was less of an electoral problem than the keystone of the imperial part of the tariff agenda - duties on imports of foreign raw materials and food.

The greatest weakness of tariff reform was popular concern about its effect upon the cost of living, and this was exacerbated by the denunciations of 'food taxes' from the Liberal and Labour parties, both of which remained staunch supporters of free trade. The reluctance of working-class voters to abandon free trade was even more of a difficulty after the extension of the franchise in 1918, and women voters were expected to be particularly fearful of the effects on their household budgets. ${ }^{58}$ On several occasions, electoral pragmatism prompted Conservative leaders to pledge not to introduce food duties or move towards a general tariff during the next Parliament. This was a necessary foundation for continuing the Coalition in 1918, and was generally perceived as crucial in the party's first electoral victories in over two decades in 1922 and 1924 . Only in 1929 was such denial rewarded with defeat, with significant effects in causing the party crisis over food taxes in the next two years. However, such pledges were only a postponment as part of an incremental strategy: food duties could not be dropped permanently, as they were an essential part of the policy. The keystone of Chamberlain's programme was the establishment of a system of imperial preference, by which empire produce would have advantageous access to the British domestic market by paying a lower tariff than foreign goods (or perhaps paying no duty at all - this was the proposal urged by Lord Beaverbrook's 'Empire Crusade' tariff campaign in 1929-31, under the ambiguous slogan 'empire free trade'). In return, British manufactured exports would have a similarly privileged position in the Dominion markets, and the whole process would strengthen the economic links within the empire and counteract its tendency to devolve into separate selfinterested states.

The problem was that most Dominion exports to Britain were raw materials and food, and so imperial preference could not be implemented without the introduction of duties on other foreign 
imports in these categories. Tariffs on foodstuffs were also being pressed for by British agriculture, although this was primarily defensive protectionism due to by the severe depression which affected most of this sector in the inter-war period. The combined result was a powerful undercurrent of support in the parliamentary party and the constituencies for the full 'whole-hog' tariff policy. This was sometimes suppressed in the face of greater political dangers, but was always latent and explains the buoyancy of support for the staunchly protectionist 'diehard' right and the appeal of the 'Empire Crusade' to grass-roots opinion in the safe seats and the agricultural regions in 192930. Many of the committed supporters of tariff reform had entered politics as young men in the Edwardian period largely due to its evocation of patriotism and empire; the most constant advocate at cabinet level in the 1920 s was Amery, and the most tireless campaigner on the backbenches was Croft. For many, it was what made the Conservative Party distinctive and gave it purpose: when the prospect of a Labour government in 1924 led some to urge the ditching of key parts of the programme, Amery responded that 'a Conservative Party today which is not preferentialist or protectionist is an abortion; it is just the old Coalition with a reduced and weakened personnel'. ${ }^{59}$ The policy had an appeal beyond the limited number of the 'diehards', as shown by the welcome given by mainstream MPs to a full tariff programme in 1923 and 1930 . Typical of this was the approbation of the senior backbencher Herbert Spender-Clay during the 1923 election campaign: 'our party has too often been content to remain on the defensive'. ${ }^{60}$ However, the electoral difficulties were such that MPs and constituency associations in the industrial regions tended to 'suffer from "nerves" the moment Protection is brought forward', and so the policy was always to some extent divisive and it was impossible to get it presented with consistency or complete enthusiasm. $^{61}$

On two occasions between the wars the Conservatives fought a general election advocating a full protectionist programme. The first of these was 1923, when tariffs were the main issue of the campaign. Although the timing of the election itself slipped out of Baldwin's control, the choice of the policy was deliberate. It seemed to Baldwin and several of his key cabinet colleagues to be the 
only possible solution to the economic and political problems which were mounting in the autumn of 1923. The existence of a stable Conservative government had not produced the hoped-for improvement in business confidence and recovery of the economy. The high and rising level of unemployment was a serious problem in itself and the key factor in the advance of the Labour Party, and Baldwin was very reluctant to enter another winter without some positive remedy. ${ }^{62}$ In addition, the severe and continuing depression in agriculture raised the issue of protectionist measures that would affect food imports. The question was given further impetus by the call of the Dominion prime ministers at the Imperial Conference in October 1923 for a system of imperial preference, and Conservatives were aware that without a response the empire would drift further apart. Despite Baldwin's efforts, there had been little improvement in relations with France, concern over which had been an important factor in turning Conservative opinion against the Coalition. In general, during its first year in office the government had been competent but uninspiring, and as the months passed increasingly it seemed to be dull and lacking in initiative. There was a need for a bold step to recover ground from the opposition and enthuse Conservative supporters, and the members of the cabinet - including Baldwin - who had entered politics supporting Joseph Chamberlain's policy needed little encouragement to turn to it as the answer to their difficulties. Parliamentary opinion was also moving in this direction, with 103 MPs signing a petition in favour of preference initiated by the 'diehard' leader John Gretton at the end of July. ${ }^{63}$

These were the real and logical reasons why Baldwin needed to free his hands from the pledge against the introduction of tariffs given by Law in the general election of 1922. Although Baldwin had served only a few months as Prime Minister and the Conservative Party had a secure majority in a Parliament which still had up to four years to run, there was no way that was consistent with honour by which a move to protection could be made without a fresh mandate from the electorate. After this had led to an unexpected dissolution, a disorganised campaign, electoral defeat, loss of office and the installation of the first Labour government, other justifications for the strategy were attributed to or even claimed by Baldwin. One of these related to the perennial fear of revived 
coalitionism: the assertion that Lloyd George was about to come out for protection and would have rallied the Conservative coalitionists to him under that standard. Baldwin later claimed this as a motivation in conversation with Tom Jones, but there is no sign that it was a factor at the time or any clear evidence that Lloyd George was contemplating such a plan. ${ }^{64}$ At the most, this may have influenced the timing of the announcement, but it was not the reason for adopting the policy. When the brief and moderate first Labour government was followed by a Conservative landslide in the 1924 election, it was possible with the wisdom of hindsight to consider that giving them a taste of office in this way had been beneficial. In fact, before the 1923 poll, very few had shared the view of Earl Winterton MP that 'the best way to crush the Labour Party is to let it be in power for a short time'. ${ }^{65}$

An even more convoluted explanation was that it had been a subtle tactical move to reunite the Conservative Party after the division in October 1922 over continuing the coalition under Lloyd George, without needing to make concessions to the former pro-coalitionist wing. The latter's protectionist loyalties - especially in Austen Chamberlain's case - meant that they had to support the new leadership without gaining concessions or even membership of the cabinet, thereby widening the distance between themselves and the Liberal coalitionists. In reality, this was a secondary objective at the most; it was useful, but no better than a consolation prize. The idea that Baldwin had risked everything (or, even more ludicrously, had deliberately led the party into defeat) for that purpose is absurd; his aim was to win the election and introduce the economic policy which he and many other Conservatives had supported for two decades and sincerely believed was the best way to tackle Britain's most fundamental industrial, financial, social and imperial problems. ${ }^{66}$ There is every indication that when Baldwin announced his plan to the cabinet on 23 October he intended, and they expected, a propaganda campaign through the winter and that 'an election would not be necessary before the spring of 1924'. ${ }^{67}$ After unveiling his programme to the party conference at Plymouth on 25 October, Baldwin told Sir William Bull that it was 'certainly not' the case that it would to lead to an immediate election. ${ }^{68}$ This proved to be a 
miscalculation: once the ball was set rolling it gathered such weight and momentum that an election rapidly became unavoidable, but the announcement of the dissolution on 13 November was the product of necessity rather than intention. An important final consideration was that many MPs were leaving Westminster to defend their constituencies; the Chief Whip feared an imminent defeat in the House, and to be forced to go to the country after such a humiliating reverse would be worse than seizing the initiative. ${ }^{69}$ Of course, when the election resulted in defeat there was plenty of criticism and benefit of hindsight, and Baldwin was understandably blamed in many quarters, especially by MPs and constituencies who had fallen to the opposition.

The defeat of 1923 taught Baldwin a severe lesson in the difficulty of persuading a mass electorate of the need for tariffs. The policy was shelved as quickly as dignity would allow, and at the next general election in October 1924 a renewed pledge not to introduce protection was regarded as essential for success - an opinion apparently vindicated by the landslide victory. Having recovered office, the Conservatives restricted themselves to restoring the minor and targeted protection of the McKenna Duties, introduced as a wartime expedient by a Liberal Chancellor of the Exchequer in 1915 and repealed by the first Labour Government in 1924. Beyond this, in the 1924-29 parliamemnt the Conservatives returned to the concept of limited shelter for specific industries which were under severe foreign competition: the policy of 'safeguarding', first introduced by Baldwin in 1921 when he was President of the Board of Trade in the Lloyd George Coalition. This was restricted to manufacturing industries and thus steered clear of any question of food taxes, but it was therefore of no assistance to domestic agriculture or reciprocal trade within the empire. In addition, it could not be applied to major sectors of industry as this would appear to be introducing protection by the back door and breaching the election pledge, in spirit if not in letter. ${ }^{70}$ For these reasons, safeguarding had strict limitations and conditions. The trade in question had to organise itself and apply under a formal procedure, and it was a condition that this included plans to restructure and modernise the industry; the tariff protection was granted to enable this improvement to take place, and not as a perpetual crutch for 
inefficient businesses. During the 1924-29 Parliament there were grumbles that the restrictions were too severe and the procedure too complicated, so that too few of the beleagoured trades were being assisted; by 1928, less than one per cent of the industrial workforce were employed in safeguarded trades. ${ }^{71}$ There remained widespread support for protectionism amongst MPs and the grass-roots, who expected the government to advance 'even to the utmost stretching of our pledges'. ${ }^{72}$ In the final two years of the government, increasing pressure built up within the parliamentary party, fostered by the Empire Industries Association, for the extension of safeguarding to iron and steel. ${ }^{73}$ This was resisted, in particular by Churchill at the Treasury, because it involved too large and central a part of the economy; his argument that 'our safeguarding policy is far too restricted to carry the weight of a fundamental issue of this kind' carrying the day. ${ }^{74}$ Baldwin considered that extending safeguarding to such a major economic sector in this parliament would be a breach of his pledge of 1924; even more crucially, he ruled it out of the party manifesto for the next election, and made this clear in a public letter to the Chief Whip and to a deputation of MPs from the Empire Industries Association in July and August $1928 .^{75}$

Defeat in the 1929 general election discredited Baldwin's cautious strategy, and tariff policy was the major issue in the internal discord during the period in opposition to the second Labour government of 1929-31. The extension of safeguarding to most of industry, and iron and steel in particular, was the simplest and least politically dangerous demand. The worsening agricultural depression increased the pressure for some form of assistance to farmers, although there was an effort to avoid food tariffs by such expedients as subsidies or placing quota limits on the quantity of foreign imports. From mid-1930 onwards the impact of the slump raised the need for basic protection of the home market, through what was termed the 'emergency' or 'revenue' tariff - in the latter case, as a solution to problem of the budget deficit as well as the imbalance of trade. Finally, the campaign mounted by Beaverbrook for 'Empire Free Trade', which was effectively imperial preference under a more attractive slogan, put the issue of food taxes in the spotlight. The popularity of his 'Empire Crusade' with constituency opinion, especially in the safer seats of the 
midlands and south and in the arable farming areas of eastern England, combined with the powerful propaganda weapon of the mass circulation newspapers owned by Beaverbrook and his ally, Lord Rothermere, alarmed many Conservative MPs and placed the leadership under mounting pressure during the summer and autumn of $1930 .^{76}$

Baldwin's initial resistance to adopting a tariff policy was based upon electoral pragmatism. ${ }^{77}$ Until September 1930 he was caught in the dilemma that the pressure for tariffs from the Conservative strongholds in the south and east was countered by the reluctance of the urban midlands and north to have any hint of food taxes. The recovery of seats in the latter areas which had been lost in 1929 was essential for victory, and the possibility of a sudden election meant that the Conservatives could not afford the liability of a policy which was out of step with the public mood in the marginals. However, the combination of restiveness in the safe seats and the press lords' campaign led to a recurring cycle of crises over tariff policy - and ultimately Baldwin's leadership - which had the effect of moving the official programme in incremental steps to a full programme of protection by October 1930. The first step was signalled in Baldwin's address to the party conference in November 1929, in which he endorsed a vague and aspirational resolution on empire trade that had been moved by Croft. In March 1930, Baldwin came to an agreement with Beaverbrook upon the referendum strategy, under which at the next election the party would seek a mandate to negotiate preferential agreements with the Dominions, but these would not be implemented until approved by the British electorate in a subsequent referendum. Although it aimed to postpone the question of food taxes from the next general election, this was a move towards protection - unlike the previous adoption of the device in 1910 - and was sufficient to persuade Beaverbrook to suspend his attacks and co-operate with the party leadership.

This truce lasted until May 1930, when it broke down principally due to the caution of Baldwin's 'Home and Empire' campaign. These speeeches were delivered in northern industrial towns and aimed at the much less advanced state of opinion there; Baldwin gave the main emphasis to extending safeguarding - now to include iron and steel - and little to the imperial preference part 
of the programme about which Beaverbrook and many Conservatives cared the most. Complaining that the referendum was being used as a shield rather than a sword, Beaverbrook became convinced that Baldwin would never move to a full tariff policy and reopened hostilities with the aim of removing him. ${ }^{78}$ Misjudgements by the press lords allowed Baldwin to score a tactical success at a party meeting on 24 June 1930, but the failure to appease the growing demand within the party for a more advanced protectionist programme meant this was only a short-term relief. By September 1930 the situation had become critical, but Baldwin was able to recover due to a change in the strategic situation and a tactical opportunity. The former was the first signs that the rise of unemployment due to the world depression was affecting public opinion in the industrial areas and eroding working-class confidence in free trade and the Labour government. ${ }^{79}$ This greatly reduced the electoral dangers of a move towards protection, and by early October the shadow cabinet was looking for a way of unveiling this without it appearing to be a surrender to the press lords. ${ }^{80}$ On 8 October, at the Imperial Conference being held in London, the Canadian Prime Minister, R.B. Bennett, made a public offer of preferential tariffs if the mother country would reciprocate. Neville Chamberlain, at this time Conservative Party Chairman, immediately saw the 'truly Heaven-sent opportunity' which this presented and pushed Baldwin into a rapid response. ${ }^{81}$ The referendum was dropped in favour of a 'free hand' to introduce after the next election whatever measures were necessary; as Chamberlain proudly informed Bridgeman, it was 'an amazing advance' and 'nothing remains between us and the fullest possible policy of protection'. ${ }^{82}$

The new programme was supplemented by the 'emergency tariff' of a ten per cent duty on all imports and a quota system for foreign grain. It satisfied almost all elements in the party and removed the impetus from Beaverbrook's campaign; the Lewes constituency spoke for many in welcoming the policy as 'clear, definite and acceptable' ${ }^{83}$ This was still the party's platform when the crisis of August 1931 led unexpectedly to the formation of the National Government, and an essential Conservative condition for entering this was that it did not involve any restriction upon the 'free hand'. The task of the emergency government was limited to reducing expenditure, 
balancing the budget and restoring the pound; after this, the parties would separate and there would be an immediate election which they would fight on their own manifestos. Whilst Conservatives regarded the National Government as a necessary and patriotic response to the severity of the crisis, they feared losing the long-awaited opportunity to carry protection whilst it had public support. ${ }^{84}$ At the outset, Baldwin had reassured the party that the election would come in a matter of weeks and that nothing would prevent the Conservatives from advocating their full programme, promising the party meeting at the Kingsway Hall on 28 August 'a straight fight on tariffs and against the Socialist Party, ${ }^{85}$

During September 1931 the pressures of the situation made it important for the government to remain in place and seek an endorsement from the electorate, but the Conservatives would only accept this if they were able to campaign for the 'free hand'. This proved to be an insuperable barrier to agreeing a common fiscal policy, and after a series of difficult cabinet meetings it seemed on 5 October that the government would break up. However, at the last minute the Liberal leader, Sir Herbert Samuel, suggested a compromise: there would be no official statement from the government on tariffs, and the parties supporting it would propose their own policies. This became the 'doctor's mandate' - an appeal for public support on the basis that after the election the government would adopt whatever remedy seemed best. Although this avoided committing the government to tariffs, it was acceptable to the Conservatives for two reasons: firstly, it was effectively another form of 'free hand' and involved no hindering pledges; secondly, the large preponderance of Conservative candidates fighting under the National banner made it almost certain that their policy would have majority support if the election was won, and thus they would carry the day in the next parliament.

The general election of 1931 was the second time in the inter-war period that the Conservatives fought on a protectionist manifesto, and the first time ever that this proved to be a vote-winner rather than an electoral albatross. The Conservative leaders hoped to win around 320 to 350 seats and did not anticipate the huge scale of the landslide, with 473 Conservatives amongst the 554 
National government supporters elected. ${ }^{86}$ In one sense that settled the verdict on tariffs, but there remained some hurdles to overcome. The first of these was opposition from some of the Liberal ministers and Snowden, the Labour former Chancellor of the Exchequer, who constituted the significant minority of free traders in the full-size cabinet which was formed after the election. The Conservatives had the parliamentary big battalions, but could not use them in a directly coercive way in case this broke up the government or destroyed its national character. The Liberals were much less essential than MacDonald, but it was likely that if they were pushed into resignation the Prime Minister would considered his position untenable and go as well. There were further tense cabinet meetings in November and December 1931, until a solution was found by Hailsham in the form of another 'agreement to differ', by which normal cabinet collective responsibility would be set aside on this one issue only. ${ }^{87}$ This allowed the Liberal ministers to speak and vote against the Import Duties Bill of January 1932, which introduced the emergency tariff, whilst enabling the Conservatives to ensure its passage. The next stage took longer: the summoning of an Imperial Conference, held at Ottawa in July and August 1932, to negotiate a preferential tariff system. When this came to the cabinet on 28 September 1932, it provoked the resignation of Snowden and the Liberal followers of Samuel, but MacDonald and other key figures remained. The government was by now much more secure and could survive such a disagreement, and its national character was preserved by the appointment of Liberals from Sir John Simon's wing of the party in place of the departed Samuelites. It was only after this that a system of imperial preference was finally established; in an emotional moment, it was introduced by the Chancellor of the Exchequer, Neville Chamberlain, nearly three decades after his father had launched the campaign for tariffs in 1903.

The move to a protectionist economic system in 1932 was not simply a response to the financial crisis of 1931 , or even to the steeply rising level of unemployment since $1930{ }^{88}$ These adverse circumstances certainly made a considerable difference by eroding the support for free trade amongst key leading figures in the Labour and Liberal parties who joined the National Government and most importantly by similarly affecting public opinion, especially in the industrial areas. This 
movement of opinion was perceptible from the autumn of 1930 onwards, and together with the ineffectiveness of the minority Labour government and the deepening bite of recession, it muted the resistance to protectionism of the remaining free-trade inclined Conservatives such as Churchill, Derby and Salisbury (with the rousing of the Conservative grass-roots in the party's strongholds by Beaverbrook's 'Empire Crusade' being an additional encouragement to acquiescence). This maintained Conservative unity at the leadership level when Baldwin moved incrementally towards the 'free hand' on tariffs, although until he satisfied the rising rank and file demands in October 1930 the press lords' campaign was a real cause of tension and difficulty. The introduction of protection was primarily due to the long-standing belief in its merits and necessity on the part of the large majority of the Conservative Party, at all levels including its leaders, since the days of Joseph Chamberlain's Edwardian tariff reform campaign. This belief was delayed but not abandoned due to the needs of coalition in 1918-22 and of electoral pragmatism in 1922, 1924 and 1929. It was latent throughout the 1918-32 period, and was brought to the forefront by worsening trade and employment trends in 1922-23, in the later 1920s over the pressure to safeguard iron and steel, and by the slump in 1930-31.

The implementation of tariffs in 1932 was a further extension of the role of the state as an economic regulator and of its responsibility to shelter and provide for its citizens. ${ }^{89}$ In this respect, it was part of a slow but steady augmentation of government activity in the interwar era, falling between the Poor Law and local government reforms of the late 1920s and the rationalisation schemes, housing measures and regional policy of the 1930s. Few Conservatives - especially in the beleagoured agricultural sector - objected to enhancing measures of state assistance such as the marketing boards, although 'planning' was a more problematic issue in the 1930 s as it had the potential (especially in Labour hands) to go too far in giving direction to enterprises, rather than just establishing a regulatory framework or providing support. All of these measures demonstrated the development of Conservative attitudes between the wars, which the Second World War certainly extended further but did not overturn or transform. The suggestion by the later stages of 
the war that 'public works, public control of monopolies, public utilities, all have their part to play in the orderly development of a modern nation's resources' was not out of tune with mainstream Conservative opinion in the 1920s and 1930s, and no more advanced than the progressive agenda of the younger 'Y.M.C.A.' group of MPs in 1924-29. ${ }^{90}$ Indeed, by the early 1930 s, such an orthodox figure as Neville Chamberlain could state as an incontrovertible and uncontroversial fact 'that laissez-faire was completely dead'. ${ }^{91}$ The establishment of a wider role for the state between the wars made an accommodation to Labour's reforms after 1945 that much easier, although Conservatives still held throughout to the principle that state intervention should be restricted to 'practical expedients to supplement private enterprise', and so logically to their sole denationalisation of the iron and steel industry after returning to office in $1951 .^{92}$ 
1 G.K. Fry, The Growth of Government: The Development of Ideas about the Role of the State and the Machinery and Functions of Government in Britain since 1780 (1979); K.

Middlemas, Politics in Industrial Society (1979); W.H. Greenleaf, The British Political Tradition, Volume 3: A Much Governed Nation (1987); J. Tomlinson, Public Policy and the Economy since 1900 (Oxford, 1990); J.E. Cronin, The Politics of State Expansion: War, State and Society in Twentieth-Century Britain (1991); D. Gladstone, The TwentiethCentury Welfare State (Basingstoke, 1999); P. Harling, The Modern British State: An Historical Introduction (Cambridge, 2001); S. Edgerton, Warfare State: Britain 1920-1970 (Cambridge, 2006).

E.H.H. Green, 'Conservatism, the State and civil society in the twentieth century', in E.H.H. Green, Ideologies of Conservatism (Oxford, 2002) [hereafter Green, Ideologies of Conservatism], devotes only five of its forty pages to the inter-war period: $242,263-5,268$ 70; M. Francis, "'Set the people free"? Conservatives and the State, 1920-1960', The Conservatives and British Society 1880-1990, eds. M. Francis \& I. Zweiniger-Bargielowska (Cardiff, 1996), 58-77, only focuses on social-morality issues when discussing the 1920s. See also K. Middlemas, 'The Party, industry and the City', Conservative Century: The Conservative Party since 1900, eds. A. Seldon \& S. Ball ((Oxford, 1994), 445-97; W.R. Garside, 'Party politics, political economy and British protectionism 1919-1932' [hereafter Garside, 'Party politics, political economy and British protectionism'], History, 83, no. 269 (1998), 47-65; M. Daunton, 'How to pay for the War: State, society and taxation in Britain 1917-1924', English Historical Review, 109 (1996), 882-919; C.J. Nottingham, 'Recasting bourgeois Britain? The British state in the years which followed the First World War', International Review of Social History, 31, no. 3 (1986), 227-47; W.R. Garside, British Unemployment 1919-1939: A Study in Public Policy (Cambridge, 1990); R. Lowe, Adjusting to Democracy: The Role of the Ministry of Labour in British Politics 1916-1939 
(Oxford, 1986).

R. Self, Tories and Tariffs: The Conservative Party and the Politics of Tariff Reform 19221932 (New York, 1986); M. Cowling, The Impact of Labour 1920-1924 (Cambridge, 1971); P. Williamson, National Crisis and National Government: British Politics, the Economy and Empire 1926-1932 (Cambridge, 1992).

N. Thompson, Political Economy and the Labour Party: The Economics of Democratic Socialism 1884-1995 (1996); J. Tomlinson, The Unequal Struggle? British Socialism and the Capitalist Enterprise (1982): D. Coates, The Labour Party and the Struggle for Socialism (Cambridge, 1975); E. Durbin, New Jerusalems: The Labour Party and the Economics of Democratic Socialism (1985); A. Thorpe, 'The industrial meaning of 'gradualism': the Labour Party and industry 1918-1931', Journal of British Studies, 35, no. 1 (1996), 84-113; R. McKibbin, 'The economic policy of the second Labour Government 1929-1931', Past and Present, 68 (1975), 95-123; D. Tanner, 'Political leadership, intellectual debate and economic policy during the second Labour Government 1929-1931', The Strange Survival of Liberal England, eds. E.H.H. Green \& D. Tanner (Cambridge, 2007), 113-150; A. Booth, 'How long are Light Years in British politics? The Labour Party's economic ideas in the 1930s', Twentieth Century British History, 7, no. 1 (1996), 126; R. Toye, The Labour Party and the Planned Economy 1931-1951 (2003). Scottish Unionist Whip's Office, The Choice: Unionist Principles versus Socialism (Edinburgh, 1936) [hereafter The Choice], 5. Lord H. Cecil, Conservatism (1912) [hereafter Cecil, Conservatism], 165, 168-9, 195. R. Northam, Conservatism: The Only Way (1939) [hereafter Northam, Conservatism], 105. K. Pickthorn, Principles and Prejudices (1943), 16-17.

K. Feiling, What Is Conservatism? (1930) [hereafter Feiling, What Is Conservatism?], 15. B. Braine, Conservatism - As A Young Man Sees It (1939), 7; L.S. Amery, The Forward 
View (1935), 417; P. Loftus, The Creed of a Tory (1926), 37; D. Crisp (ed.), The Rebirth of Conservatism (1931) [hereafter Crisp, Rebirth of Conservatism], 24-6.

The Choice, 35.

Cecil, Conservatism, 150, 153.

W.H. Greenleaf, The British Political Tradition: Volume 2, The Ideological Heritage (1983), 189 et seq.; Green, Ideologies of Conservatism, 241.

Memo by Salisbury, 'Post War Conservative Policy at Home and in External Relations', first draft, 3 July 1941, Swinton MSS (Churchill College, Cambridge), II(270)/5/1.

Green, Ideologies of Conservatism, 241, 261.

Northam, Conservatism, 106-7.

Sir R.M. Banks, The Conservative Outlook (1929), 265.

Cecil, Conservatism, 189-90.

Conservative Research Department memo, 'The relations between the state and industry', Dec. 1934, Conservative Party Archive (Bodleian Library) [hereafter CPA], CRD/1/64/5. Feiling, What Is Conservatism?, 14.

Crisp, Rebirth of Conservatism, 44-7; A. Bryant, The Spirit of Conservatism (1929) [hereafter Bryant, Spirit of Conservatism], 84.

R. Boothby, G. Loder, H. Macmillan \& O. Stanley, Industry and the State: A Conservative View (1927) [hereafter Boothby et al., Industry and the State], 18-19.

Bledisloe to Baldwin, 31 Jan. 1924, Baldwin MSS (Cambridge University Library) [hereafter Baldwin MSS], 159/183-4.

Cecil to Baldwin, 1 Feb. 1924, Baldwin MSS, 35/203-7.

Feiling, What Is Conservatism?, 16.

Cecil, Conservatism, 169-70.

Cecil, Conservatism, 195-6. 
Paton to Duchess of Atholl, 1 May 1937, Atholl MSS (Blair Atholl), 22/18.

Amery to Baldwin, 13 Nov. 1923, Baldwin MSS, 42/117-24.

Crawford to Irwin, 11 Mar. 1927, Halifax MSS (British Library) [hereafter Halifax MSS], C152/17/1/196b.

Bryant, Spirit of Conservatism, 32.

Crawford to Irwin, 13 July 1928, Halifax MSS, C152/18/1/90a.

Bayford diary, 16 \& 21 Mar. 1919, Real Old Tory Politics: The Political Diaries of Sir Robert Sanders, Lord Bayford, 1910-1935, ed. J. Ramsden (1984), 124.

D. Stelling, Why I Am A Conservative (1943) [hereafter Stelling, Why I Am A Conservative], 26.

Cunliffe-Lister to Croft, 17 July 1930, Croft MSS (Churchill College, Cambridge) [hereafter Croft MSS], 1/19/Sw1.

Hoare to Irwin, 29 Apr 1926, Halifax MSS, C152/17/1/22a.

Holt to Herbert, 11 Oct. 1925, Baldwin MSS, 160/90-93.

Lane-Fox to Irwin, 13 Apr 1927, Halifax MSS, C152/17/1/208.

S. Ball, 'The 1922 Committee: the formative years 1922-1945', Parliamentary History, 9 (1990), 141-3.

Lane-Fox to Irwin, 9 Nov. 1926, Halifax MSS, C152/17/1/136; Betterton to Irwin, 26 Nov. 1926, Halifax MSS, C152/17/1/148.

R. Cecil to Irwin, 22 June 1926, Halifax MSS, C152/17/1/58.

Churchill to Baldwin, 10 Jan. 1927, Baldwin MSS, 162/68-73.

P. Williamson, Stanley Baldwin: Conservative Leadership and National Values (Cambridge, 1999), 167-202.

R. Cecil to Irwin, 7 June 1927, Halifax MSS, C152/17/1/227a.

N. Skelton, Constructive Conservatism (1924), 25-8. 
D. Ritschel, The Politics of Planning: the Debate on Economic Planning in Britain in the 1930s (Oxford, 1997).

For a general review, see Garside, British Unemployment 1919-1939.

Mackenzie King diary, 20 Oct. 1923, in P. Williamson \& E. Baldwin (eds.), Baldwin Papers: A Conservative Statesman 1908-1947 (Cambridge, 2004) [hereafter Baldwin Papers], 118.

Cabinet minutes, 23 Oct. 1923, Baldwin Papers, 123.

Mackenzie King diary, 20 Oct. 1923, Baldwin Papers, 118.

Baird to Baldwin, 31 Oct. 1924, Baldwin MSS, 42/209-12.

Memo by Davidson, 24 Jan. 1927, Davidson MSS (Parliamentary Archives), 180; Churchill to Baldwin, 6 June 1927, Baldwin MSS, 5/125-35.

Bridgeman to Worthington-Evans, 16 Sep. 1927, Worthington-Evans MSS (Bodleian Library) [hereafter Worthington-Evans MSS], Eng. Hist. c.895/73-4.

Croft to Baldwin, 31 Oct. 1923, Baldwin MSS, 35/55-6.

Keymer to Baldwin, 11 Dec. 1923, Baldwin MSS, 35/122-123.

F. Capie, 'The pressure for tariff protection in Britain 1916-1931', Journal of European Economic History, 9, no. 2 (1980), 431-48.

A. Marrison, British Business and Protection 1903-1932 (Oxford, 1996).

Wilson to Wood, 12 Dec. 1923, Baldwin MSS, 42/145-6.

Amery to Baldwin, 28 Jan. 1924, Baldwin MSS, 42/166-73.

Spender-Clay to Baldwin, 6 Dec. 1923, Baldwin MSS, 35/120-1.

Shirley Benn to Baldwin, 8 Nov. 1923, Baldwin MSS, 35/75-6.

Mackenzie King diary, 20 Oct. 1923, Baldwin Papers, 118; for similar concerns, see Winterton to Lytton, 11 July 1923, Lytton MSS (British Library) [hereafter Lytton MSS], F160/26/15-24 
R. Self, 'Conservative reunion and the general election of 1923: a reassessment', 20th Century British History, 3, no. 3 (1992), 253-8.

T. Jones, Lord Baldwin: A Memoir (1947), 8.

Winterton to Lytton, 8 Nov. 1923, Lytton MSS, F160/26/25-33.

Wilson to Baldwin, 30 Dec. 1923, Baldwin MSS, 35/195-8; Cabinet minutes, 23 Oct. 1923, Baldwin Papers, 123.

Memo by Wood, 'Record of some events preceding the dissolution and general election, November-December 1923', Baldwin MSS, 35/9-15; Derby diary, 14 Nov. 1924 Derby MSS (Liverpool Record Office), DER(17)/29/1 [hereafter Derby diary].

Bull diary, 25 Oct. 1923, end of year summary 1923, Bull MSS (Churchill College, Cambridge), 6/5, 5/12.

Derby diary, 12 Nov. 1923.

Steel-Maitland to Baldwin, 29 Oct. 1925, Baldwin MSS, 27/225-8.

Garside, 'Party politics, political economy and British protectionism', 51-2.

Amery to Baldwin, 10 Apr. 1927, Baldwin MSS, 28/251-62.

Croft to Baldwin, 17 Sep. 1928, Croft MSS, 1/3/Ba4.

Churchill to Baldwin, 19 \& 12 June 1925, Baldwin MSS, 160/21-5, 28/41-8.

Lane-Fox to Irwin, 1 Aug. 1928, Halifax MSS, C152/18/1/106.

S. Ball, Baldwin and the Conservative Party: The Crisis of 1929-1931 (1988), 46-98.

Salisbury, memo of conversation with Baldwin, 28 Jan. 1930, Salisbury MSS (Hatfield House) [hereafter Salisbury MSS], S(4)133/67-71.

Beaverbrook to Hoare, 15 May 1930, Templewood MSS (Cambridge University Library), VI/I; Beaverbrook to Croft, 19 May 1930, Beaverbrook MSS (Parliamentary Archives), $\mathrm{C} / 101$.

Worthington-Evans to his nephew, 25 Nov. 1930, Worthington-Evans MSS, Eng. Hist. 
c.897, 280-1.

Neville Chamberlain to Bridgeman, 8 Oct. 1930, Neville Chamberlain MSS (Birmingham University Library), 8/10/13d.

Neville Chamberlain to Salisbury, 11 Oct. 1930, Salisbury MSS, S(4)137/60-2.

Neville Chamberlain to Bridgeman, 15 Oct. 1930, Bridgeman MSS (Shropshire Record Office), SRO 3389/102.

Lewes Conservative Association, Executive Ctte., 27 Oct. 1930 (East Sussex Record Office); Ball, Baldwin and the Conservative Party, 101.

1922 Committee opinion in Lady Peto diary, 30 Sep. 1931, Peto MSS (Woodbridge, Suffolk); Amery to Scott, 11 Sep. 1931, Scott MSS (Warwick University Library), 119/3/P/AM/1. Amery diary, 27 Aug. 1931, Amery MSS (Churchill College, Cambridge); Baldwin to Croft, 26 Aug. 1931, Croft MSS 1/2/Ba10.

Austen to Ivy Chamberlain, 7 \& 8 Oct. 1931, Austen Chamberlain MSS (Birmingham University Library), 6/1/825-6.

Wrench, D.J., “"The needs of the time": the National Government and the Agreement to Differ, 1932', Parliamentary History, 23, no. 2 (2004), 249-64.

Garside, 'Party politics, political economy and British protectionism', 47-8, 64-5; F. Capie, Depression and Protectionism: Britain between the Wars (1983); R. Boyce, British Capitalism at the Crossroads 1919-1932 (Cambridge, 1987).

A. Booth, 'Britain in the 1930s: a managed economy', Economic History Review, 2 nd series, 40 (1987), 499-522.

Stelling, Why I Am A Conservative, 13; R.V. Jenner, Will Conservatism Survive? (1944), 31; Boothby et al., Industry and the State. Conservative Research Department, minutes of meeting, 2 Mar. 1934, CPA, CRD/1/64/5. 
Stelling, Why I Am A Conservative, 13. 